\title{
Empowerment of "meronce" hand crafts through training of on-line marketing strategy in the order to increase the income of the family in the village of Merawan Dolok, Dolok Merawan, district, on-line market
}

\author{
Badaruddin $^{1 *}$, Erika Revida ${ }^{1}$, Lina Sudarwati ${ }^{1}$ \\ ${ }^{1}$ Universitas Sumatera Utara, Medan - Indonesia \\ *Email: badaru_69@yahoo.com
}

\begin{abstract}
The "Melati" Joint Business Group is a group of women's skills including the "Meronce" craftsmanship whose members consist of women in Dolok Merawan Village, Dolok Merawan District, Serdang Bedagai Regency, North Sumatra Province. The results of the 2018 community service program for this business group have shown quite encouraging results, in which this joint business group has been able to increase its organizational capacity and be able to improve its "meronce" handicraft skills by producing products of economic value. However, the "Melati" Joint Business Group is experiencing difficulties in marketing its handicraft products, because so far the method of selling products is still conventional, and they have not been able to market their products online. This community service activity aims to train the "Melati" Joint Business Group in relation to the online marketing strategy of the "Meronce" handicraft products. To achieve these objectives, the service methods used are lecture and discussion techniques, training on the promotion of handicraft products online by providing promotional tools, namely smartphones and equipment, and strengthening group organizations with on-line marketing strategy training. The results of the service activities show that KUBE Melati members already have the ability to market their craft products online such as Facebook and WhatsApp, and there are even consumers who order online. This is enough to motivate them so that they do not feel left behind by the progress of Information Technology in marketing their handicrafts. But they still hope that the service team can provide assistance for them in accordance with the progress of the Information Technology.
\end{abstract}

Keywords: Increasing women's capacity, skills, online marketing

\begin{abstract}
Abstrak
Kelompok Usaha Bersama "Melati" adalah kelompok keterampilan perempuan diantaranya adalah keterampilan kerajinan tangan "Meronce" yang anggotanya terdiri dari kaum perempuan yang ada di Desa Dolok Merawan, Kecamatan Dolok Merawan, Kabupaten Serdang Bedagai, Provinsi Sumatera Utara. Hasil dari program pengabdian tahun 2018 terhadap kelompok usaha ini telah menujukkan hasil yang cukup mengembirakan, di mana kelompok usaha bersama ini telah mampu meningkatkan kapasitas organisasinya dan mampu meningkatkan keterampilan kerajinan tangan "meronce" dengan menghasilkan produk-produk bernilai ekonomis. Meski demikian, Kelompok Usaha Bersama "Melati" ini mengalami kesulitan dalam memasarkan produk kerajinan tangannya, sebab selama ini metode penjualan produk masih bersifat konvensional, dan mereka belum mampu untuk memasarkan produk mereka secara online. Kegiatan pengabdian masyarakat ini bertujuan untuk melatih Kelompok Usaha Bersama "Melati" terkait dengan strategi pemasaran produk kerajinan tangan "Meronce" secara on-line. Untuk mencapai tujuan tersebut, maka metode pengabdian yang digunakan adalah teknik ceramah dan diskusi, pelatihan promosi produk kerajinan tangan secara online dengan memberikan bantuan alat promosi yaitu smartphone dan perlengkapannya, serta memperkuat organisasi kelompok dengan pelatihan strategi pemasaraan on-line.Hasil dari kegiatan pengabdian menunjukkan bahwa anggota KUBE Melati telah memiliki kemampuan untuk memasarkan produk kerajinannya lewat online seperti facebook dan WhatsApp, bahkan telah ada pula konsumen yang memesan lewat online tersebut. Hal ini cukup memberi motivasi bagi mereka sehingga mereka tidak merasa tertinggalkan dengan kemajuan Tekhnologi Informasi dalam memasarkan hasil kerajinan mereka. Namun mereka tetap berharap agar tim pengabdian dapat memberikan pendampingan bagi mereka sesuai dengan kemajuan Tekhnologi Informasi tersebut.
\end{abstract}

Kata Kunci: Peningkatan kapasitas perempuan, keterampilan, pemasaran on-line 


\section{PENDAHULUAN}

\subsection{Analisis Situasi}

Ekspansi industri perkebunan terus merambah ke seluruh penjuruh Indonesia. Tekanan permintaan pasar global dan kebutuhan untuk memacu pertumbuhan ekonomi nasional mendorong terjadinya ekspansi industri perkebunan secara masif di Indonesia. Kehadirannya pun tidak hanya mendatangkan dampak positif, namun juga menghasilkan dampak negatif. Seperti yang terjadi pada masyarakat Desa Dolok Merawan Kecamatan Dolok Merawan, Kabupaten Serdang Bedagai. Desa yang memiliki luas \pm 595 Ha ini memiliki letak geografis yang dihimpit oleh perkebunan karet milik PTPN 3 Kebun Gunung Para. Keadaan geografis ini sangat memberikan pengaruh langsung terhadap kehidupan sosial ekonomi desa. Dari hasil observasi awal, keberadaan perkebunan memberikan manfaat positif bagi perekonomian masyarakat Desa Dolok Merawan, karena keberadaannya dapat menjadi sumber pemasukan rumah tangga dengan bekerja menjadi buruh perkebunan. Di sisi lain, keberadaan perkebunan memberikan dampak negatif, yaitu perkebunan menciptakan ketergantungan sistem mencari nafkah rumah tangga dari hasil menjadi buruh perekebunan, dan ketergantungan sistem nafkah rumah tangga dari hasil tanaman karet dan kelapa sawit yang merupakan hasil monokulturisasi tanaman yang dibawa oleh perkebunan industri.

Pertama, ketergantungan sistem nafkah rumah tangga dari hasil menjadi buruh perekebunan. Kondisi geografis desa yang dihimpit oleh perkebunan indutri membuat masyarakat Desa Dolok Merawan memiliki peluang pekerjaan yang sangat terbatas, sehingga menjadi buruh perkebunan dengan upah terbatas adalah profesi yang banyak dipilih oleh masyarakat desa ini. Hal ini menggambarkan perekebunan industri seolah memberikan kesejahteraan bagi rumah tangga di desa ini, namun yang terjadi adalah munculnya kerentanan dan ketergantungan nafkah yang tinggi dengan bekerja menjadi buruh perkebunan dengan upah yang rendah. Minimnya peluang mendapatkan pekerjaan di sektor lain, membuat warga menjadi tergantung dengan perkebunan.

Kedua, ketergantungan sistem nafkah rumah tangga dari hasil tanaman karet dan kelapa sawit yang merupakan hasil monokulturisasi tanaman yang dibawa oleh perkebunan industri. Di Desa Dolok Merawan, sebagian besar lahan pertanian juga digunakan untuk menanam tanaman industri seperti karet dan kepala sawit. Ketika harga produksi kedua tanaman tersebut sangat menguntungkan, maka akan meningkatkan pendapatan rumah tangga, namun jika harga produksi kedua tanaman tersebut sedang tidak menguntungkan, maka tingkat pendapatan masyarakatpun menjadi rendah. Kondisi tidak stabilnya penerimaan masyarakat dari hasil pertaniannya inipun semakin diperparah dengan tingginya alih fungsi lahan pertanian menjadi pemukiman di desa ini. Lapangan pekerjaan di bidang pertanianpun semakin banyak yang hilang seiring dengan tingginya alih fungsi lahan tersebut. Karena itu, diversifikasi (penganekaragaman) pekerjaan menjadi sangat penting dilakukan di Desa Dolok Merawan ini. Termasuk pekerjaan bagi kaum perempuan desa agar dapat ikut menopang penghasilan rumah tangga di desa ini.

Pada tahun 2018, telah ada upaya dari penulis (melalui kegiatan Pengabdian Kepada Masyarakat Skim Mono Tahun) untuk menciptakan lapangan pekerjaan baru bagi perempuan di desa ini dengan memberikan pelatihan keterampilan kerajinan tangan "meronce" (Badaruddin, dkk., 2018). Hasilnya, Kelompok Mitra yang diberikan pelatihan telah memiliki kapasitas dalam berorganisasi serta meningkatnya keahlian dan skill kelompok mitra dalam hal kegiatan kerajinan tangan (meronce).

Ketika bincang-bincang dengan mereka dapat diketahui bahwa mereka masih menginginkan adanya pelatihan "meronce", terutama pelatihan tentang bagaimana cara memasarkan hasil kerajinan tangan mereka tersebut secara online. Besarnya motivasi mitra untuk berkegiatan, terutama kegiatan yang berkontribusi pada peningkatan ekonomi/kesejahteraan keluarga, perlu mendapatkan apresiasi dalam bentuk pemberian pelatihan keterampilan penerapan iptek khususnya pelatihan strategi pemasaran secara online. Selain itu, besarnya motivasi mitra untuk dilatih juga akan mempermuda tercapainya tujuan-tujuan dari proses pemberdayaan masyarakat itu sendiri. 
Sebab, kelompok mitra akan lebih kooperatif dan bertanggung jawab dalam menjalani program pemberdayaan. Hal ini seusai dengan pandangan Marzali (2003) yang mendefinisikan pengembangan masyarakat sebagai sebuah proses tindakan sosial dimana penduduk sebuah komunitas mengorganisasikan diri mereka dalam perencanaan dan tindakan, menentukan kebutuhan dan masalah individu/bersama, membuat rencana individu/kelompok untuk memenuhi kebutuhan dan menyelesaikan persoalan, melaksanakan rencana dengan menyesuaikan diri secara maksimal dengan sumberdaya yang ada dalam komunitas, dan jika diperlukan menambah sumberdaya ini dengan jasa dan materi dari badan-badan pemerintah dan non-pemerintah yang berasal dari luar komunitas.

Pemasaran produk melalui internet merupakan suatu keniscayaan di era Revolusi Industri 4.0 ini. Mengingat pada era ini arus sistem informasi telah semakin cepat dan maju, sehingga setiap individu maupun organisasi harus mampu menguasai sistem informasi dan teknologi agar dapat berkembang. Prof. Ainun Naim dalam Diklat Kepemimpinan Tingkat IV angkatan II tahun 2018 Kementerian Riset, Teknologi dan Pendidikan Tinggi (Buletin Pusdiklat Kemenristekdikti, Edisi 1 Volume 2 Tahun 2018) menyampaikan tentang pentingnya beradaptasi terhadap kemajuan teknologi di era disruptif saat ini. Ia mengatakan bahwa organisasi harus melakukan perbaikan dan mengembangkan layanan sistem informasi secara terus-menerus (continuous improvement) dalam rangka pembentukan keunggulan kompetitif agar mampu untuk bertahan dan berkembang.

E-Commerce atau toko online merupakan salah satu konsep yang cukup berkembang dalam dunia internet dan pemasaran di era disruptif saat ini. Sebab konsep E-Commerce menyediakan banyak kemudahan dan kelebihan jika dibandingkan dengan konsep belanja yang konvensional. Selain proses transaksi bisa menjadi lebih cepat, konsep toko online atau E-commerce dapat memangkas banyak biaya operasional karena penjual tidak diharuskan punya toko fisik.

\section{METODE PELAKSANAAN}

Metode pengabdian masyarakat dilakukan dengan cara penyuluhan, diskusi, tugas dan pelatihan strategi pemasaran produk kerajinan tangan "Meronce" secara online dengan melibatkan instruktur yang sudah berpengalaman dalam pemasaran online. Dalam masing-masing kegiatan terdapat penanggung jawabnya, sehingga kegiatan yang berjalan sesuai dengan yang telah ditentukan. Selama pelaksanaan tim pengusul selalu berkoordinasi dengan mitra, sehingga dalam prosesnya mitra memahami dan dapat menjalankan secara mandiri atas teknologi yang telah ditransfer melalui penyuluhan, diskusi, tugas dan pelatihan yang dilakukan secara intensif dari masingmasing kegiatan. Dalam pelaksanaan program ini, tim pengabdian selalu mengevaluasi dan melaporkan hasil kegiatan yang telah dilaksanakan sampai kegiatan terealisasi, sehingga kerjasama tim dapat terwujud, dan masing-masing anggota tim dapat mengoptimalkan potensi dan bidang pakarnya.

Mitra berkontribusi dalam memberikan gambaran permasalahan sehingga tim pengusul dapat dengan jelas menawarkan solusi. Selain itu, mitra berkontrobusi dalam menyiapkan tempat dalam melakukan ceramah dan diskusi serta mengundang orang-orang yang akan dilibatkan dalam kegiatan ini.

\section{HASIL DAN PEMBAHASAN}

Sejalan dengan metode pelaksanaan pengabdian yang sudah dipaparkan pada bagian terdahulu, yaitu melakukan kegiatan penyuluhan dan diskusi dengan kelompok mitra serta memberikan hantaran finasial dalam bentuk pemberian 1 buah handphone sebagai alat untuk memasarkan produl melalui media on-line yang dilengkapi dengan paket datanya sebanyak 5 paket data. Langkah pertama yang dilakukan pada kegiatan pengabdian kepada masyarakat ini adalah pengurusan izin melakukan kegiatan pengabdian masyarakat kepada pemerintahan desa dalam hal ini kepada Kepala Desa. 
Penyampaian surat tugas dari Ketua Lembaga Pengabdian Kepada Masyarakat (LPPM) Universitas Sumatera Utara (USU) kepada Kepala Desa Dolok Merawan disampaikan pada tanggal 11 Juni 2019. Ketua Tim Peneliti bersama 2 (dua) orang mahasiswa diterima oleh Kepala Desa beserta aparatnya. Pada pertemuan yang pertama dengan Kepala Desa dan Aparat Desa lainnya, disampaikan maksud dan tujuan kedatangan tim pengabdian sebagai tindak lanjut dari pertemuan yang pernah dilakukan sebelumnya (ketika penyusunan proposal pengabdian ini) terkait dengan kesediaan Kelompok Usaha Bersama Perempuan yang ada di desa ini sebagai mitra dari kegiatan pengabdian ini, yaitu KUBE Melati.

Pada pertemuan tersebut Kepala Desa berterima kasih karena telah menjadikan Kelompok Usaha Bersama perempuan yang ada di desanya sebagai mitra dan bersyukur karena kegiatan ini jadi dilaksanakan. Seperti yang dikemukakan oleh Kepala Desa: "Syukurlah kegiatan ini jadi dilaksanakan, karena setelah pertemuan tempo hari dengan Kelompok Mitra Melati yang ada di desa ini, mereka juga kalau ketemu sering bertanya tentang kelanjutan dari kegiatan ini. Saya bilang sama mereka kita tunggu sajalah, kalau nanti jadi akan saya kabari. Saya yakin mereka akan sangat senang mendengar kabar ini”.

Pada pertemuan yang pertama ini, saya sampaikan juga rencana-rencana kegiatan selanjutnya dan mohon bantuan dari Kepala Desa untuk memfasilitasi pertemuan dengan kelompok mitra. Pada pertemuan ini juga tim pengabdian bertemu dengan ketua kelompok dan tim berdiskusi tentang rencana dan teknis kegiatan pengabdian ini, termasuk rencana waktu pelaksanaan penyuluhan dan praktek pemasaran on-line.

Kepala Desa menyatakan kesiapannya untuk membantu dan memfasilitasi pertemuan selanjutnya dengan kelompok mitra. Setelah berdiskusi dengan aparat desa dan ketua kelompok mitra, maka disepakati bahwa tempat pertemuan untuk kegiatan penyuluhan dilakukan di Joglo depan Rumah Kepala Desa atau di Kantor Kepala Desa. Kedua tempat tersebut biasa dilakukan untuk pertemuan-pertemuan dengan warga.

Dengan mempertimbangkan kesibukan kepala desa untuk mempersiapkan berbagai hal yang terkait dengan terpilihnya Desa Dolok Merawan untuk mewakili Kabupaten Serdang Bedagai dalam perlombaan Desa terbaik tingkat Provinsi Sumatera Utara, maka pada saat itu belum bisa dipastikan kapan kegiatan penyuluhan akan dilakukan, namun disepakati akan terus dilakukan komunikasi untuk kepastian kesiapan tim pengabdian dan kesiapan kelompok mitra serta kepala desa. Kegiatan penyuluhan dan penyerahan alat (handphone dan paket data) untuk kegiatan penyuluhan dan praktek pemasaran secara on-line, disepakati dilaksanakan pada tanggal 07 Agustus 2019.

\subsection{Penyuluhan: Komunikasi Bisnis dengan Sosial Media Facebook, Whatsapp, Instagram, dan Twitter serta Penyuluhan Digital Marketing: Strategi Bagi Kelompok Usaha Bermodal Kecil untuk Memasarkan Produk}

Pelaksanaan penyuluhan dilakukan oleh tim pengabdian masyarakat dengan metode ceramah dan diskusi. Diskusi ini dihadiri oleh 10 orang peserta yang merupakan anggota dari kelompok mitra yaitu Kelompok Usaha Bersama "MELATI" ditambah dengan Kepala Desa beserta aparatnya dan juga Pengurus PKK Desa Dolok Merawan. Dalam pertemuan tersebut juga dihadiri oleh Camat Kecamatan Dolok Merawan. Ada dua materi penyuluhan yang disampaikan yaitu: 1). Komunikasi Bisnis Dengan Sosial Media Facebook, Whatsapp, Instagram, dan Twitter, dan; 2). Digital Marketing: Strategi Bagi Kelompok Usaha Bermodal Kecil Untuk Memasarkan Produk

Materi pertama disampaikan oleh Ketua Tim, dengan bahasan tentang bagaimana melakukan komunikasi bisnis dengan sosial media Facebook, Whatsapp, Instagram, dan Twitter. Sedangkan materi kedua disampaikan oleh tim dengan muatan utama isi ceramah berkisar bagaimana peran digital marketing sebagai strategi bagi kelompok usaha bermodal kecil untuk memasarkan produk. Selanjutnya, paparan disampaikan oleh mahasiswa/mahasiswi FISIP USU terkait pemasaran melalui media sosial. Paparan yang disampaikan oleh mahasiswa ini berkaitan dengan pengalaman mereka sendiri memasarkan produk secara online. Kegiatan ini dirasakan perlu mengingat pada 
perkembangan komunikasi pemasaran internet saat ini telah beralih dari cara off-line ke arah online. Perubahan ini membuat persaingan bisnis semakin ketat, sehingga mendorong pengusaha menampilkan keunggulan dan kapabilitas yang lebih baik untuk dapat berkompetisi dalam memasarkan produk dengan berbagai strategi pemasaran internet yang ada.

Setelah penyampaian materi selesai dilakukan, dilanjutkan dengan diskusi terhadap materi yang sudah disampaikan. Dalam diskusi terungkap berbagai persoalan yang menurut warga menjadi masalah dan penghambat dalam menjalankan kelompok selama ini. Persoalan yang mengemuka dari anggota kelompok mitra yaitu persoalan kekurangan modal, dan pemasaran hasil kerajinan. Namun, dari diskusi yang berjalan cukup santai, sesungguhnya banyak gagasangagasan cemerlang dari anggota kelompok mitra tentang bagaimana seharusnya kelompok ke depan dalam rangka mencapai tujuan mereka. Ceramah yang disampaikan telah membuka cakrawala berpikir mereka tentang apa sebenarnya yang dapat mereka lakukan untuk diversifikasi okupasi mereka. Harapan mereka agar kegiatan ceramah dan diskusi seperti ini dapat dilakukan secara berkelanjutan.

Salah seorang peserta (aparat desa), menawarkan agar pada masa-masa mendatang USU dapat melakukan kegiatan serupa untuk bidang ekonomi yang lain dan yang terkait dengan pemasaran secara online mengikuti perkembangan Tekhnologi Informasi yang sangat cepat sekali. Harapannya tim pengabdian beserta mahasiswa mampu terus memberi pembelajaran kepada KUBE dan masyarakat lainnya. Harapannya hasil-hasil produksi masyarakat, termasuk hasil kerajinan tangan warga dapat dipasarkan secara online. Khusus untuk kaum perempuan, menurutnya, perempuan memiliki lebih banyak waktu luang di rumah, sehingga perlu diberdayakan untuk menopang penghasilan keluarga.

\subsection{Penyerahan Bantuan Bahan dan Peralatan serta Pelatihan Pemasaran On-Line}

Setelah kegiatan ceramah dan diskusi selesai dilakukan, dilanjutkan dengan acara penyerahan bahan dan peralatan yang diperlukan kelompok untuk melakukan praktek pemasaran secara online. Sebelum penyerahan alat (handphone dan paket data) kepada ketua kelompok, terlebih dahulu dibuat acara serah terima yang ditandatangani oleh ketua kelompok dan beberapa anggota kelompok yang hadir dan disaksikan oleh Kepala Desa Dolok Merawan.

Selanjutnya ketua kelompok dipandu dengan instruktur dari tim pengabdian yang diikuti juga oleh anggota lainnya mulai membuka alat yang sudah diserahkan dan memakainya. Praktek pemasaran on-line ini dipandu oleh salah seorang instruktur tim pengabdian yang sudah mahir dan terbiasa memasarkan produknya secara on-line.

Dalam pelatihan ini, pertama-tama peserta dikenalkan dengan pengertian, manfaat, dan beberapa contoh nama media sosial yang telah dikenal masyarakat luas. Kemudian, peserta diajarkan untuk membuat email sebagai portal untuk mengakses dan membuat akun ke beberapa media sosial yang ada. Dalam praktek ini, media sosial yang dipekrenalkan dan digunakan adalah Instagram dan Facebook. Instagram dan Facebook dikenalkan kepada mitra mengingat adanya pergeseran tren masyarakat yang semakin intens dalam menggunakan telepon genggamnya untuk bersosialisasi di dunia maya khusunya melalui Instagram dan Facebook. Hasil penelitian menunjukkana bahwa Di era jejaring sosial saat ini, Facebook mendominasi industri ini dengan jumlah pengguna sebanyak $85 \%$ dari selaruh pengguna internet di seluruh dunia (www.digitalinformationworld.com, 2019). Selain dikarenakan banyakanya jumlah pengguna, pemilihan sosial media Istagram dan Facebook sebagai alat pemasaran juga bertujuan untuk menekan biaya promosi, karena pembuatan akunnya Instagram dan Facebook gratis dan mudah digunakan. Hal ini menjadikan Instagram dan Facebook memiliki peluang yang sangat besar untuk proses jual beli produk mitra.

Setelah mitra berhasil membuat akun Instagram dan Facebook, mitra kemudian diajarkan tentang cara mgetahui dan menentukan target calon audiens mitra. Tujuan pengajaran ini adalah untuk mengedukasi mitra bahwa dalam dunia pemasaran, seorang pemasar harus paham bahwa menargetkan 1 kelompok audiens jauh lebih efektif daripada yang terlalu umum. Pengajaran ini 
akan berguna pada saat mitra membuat konten dan meminimalisir kesalahan yang paling fatal dalam menggunakan bahasa yang tidak pantas buat target audiens mereka nantinya.

Selanjutnya, mitra diajarkan tips untuk membuat post yang baik di Facebook dan Instagram. Dalam membuat post, sebuah konten perlu diciptakan untuk menarik perhatian dan minat konsumen. Menurut McGurk (2014), konsumen akan tersambung dan terikat dengan suatu merek di sosial media jika terdapat sesuatu yang berarti di dalam post bagi konsumen. Dalam memanfaatkan Facebook dan Instagram, kita tidak bisa membuat post terlalu banyak dalam sehari. Alasannya yaitu: Post lebih dari 2 kali sehari akan mendapatkan lebih sedikit like, dan; Setiap post harus berkualitas, sebab sangat sulit untuk membuat banyak post berkualitas dalam sehari. Maka dari itu, setiap post harus anda pikirkan matang-matang. Untuk itula mitra kemudan diajarkan beberapa tipsnya dalam membuat post, yang isi pengajarannya yaitu:

Pertama. post berjenis teks sebaiknya tidak berdiri sendiri melainkan dibarengi gambar, video, atau link. Orang cenderung melewatkan post berupa teks karena tidak menarik. Selain itu, sulit menyampaikan pesan dengan teks karena Facebook akan memotong teks yang terlalu panjang.

Kedua, Kapan waktu terbaik untuk posting di Facebook dan Instagram? Ini sangat tergantung pada kepada siapa orang yang akan menajdi target pemasaran mitra. Jika target mitra adalah pelajar/mahasiswa maka postingan terbaik dibaut pada waktu hari kerja dan malam hari. Jika target adalah pekerja, maka postingan terbaik dapat dilakukan pada akhir minggu maupun pada malam hari. Dan jika target adalah ibu rumah tangga, maka mitra dapat membuat postingan pada hari hari kerja maupun di siang hari.

Setelah mitra dijakarkan tentang cara-cara membuat postingan di Instagram dan Facebook, mitra kemudian diperkenalkan dengan istilah-istilah yang yang terdapat dalam transaksi jual beli online, yaitu:

Tabel 3.1. Istilah Dalam Jual Beli Online

\begin{tabular}{|c|c|c|c|}
\hline Istilah & Arti & Istilah & Arti \\
\hline Seller & $\begin{array}{l}\text { penjual/pemilik toko } \\
\text { online }\end{array}$ & Sold & Barang habis terjual \\
\hline buyer & Pembeli & Trusted & Terpercaya, bukan penipu \\
\hline customer & $\begin{array}{l}\text { Sebutan untuk pembeli } \\
\text { yang loyal }\end{array}$ & Testimonial & $\begin{array}{l}\text { pesan dan kesan dari } \\
\text { pelanggan. Ini biasanya } \\
\text { dijadikan buktii untuk } \\
\text { meyakinkan pembeli lainnya } \\
\text { berdasarkan pengakuan } \\
\text { pembeli sebelumnya. }\end{array}$ \\
\hline supplier & $\begin{array}{l}\text { Pemasok barang pada } \\
\text { penjual }\end{array}$ & $\begin{array}{l}\text { DP (Down } \\
\text { Payment })\end{array}$ & $\begin{array}{l}\text { sistem pembayaran yang tidak } \\
\text { langsung dibayar lunas. Sistem } \\
\text { pembayaran ini biasanya } \\
\text { digunakan } \\
\text { untuk barang dengan sistem pre } \\
\text { order. }\end{array}$ \\
\hline Reseller & $\begin{array}{l}\text { Penjual yang menjual } \\
\text { barang orang lain untuk } \\
\text { konsumennya (bisa disebut } \\
\text { calo) }\end{array}$ & Full payment & Pembayaran penuh (lunas) \\
\hline Dropship & $\begin{array}{l}\text { Pengiriman barang kepada } \\
\text { konsumen dengan } \\
\text { mengatasnamakan pihak } \\
\text { kedua selaku reseller }\end{array}$ & Booked & $\begin{array}{l}\text { Produk telah dipesan sehingga } \\
\text { konsumen lainnya tidak dapat } \\
\text { membelinya }\end{array}$ \\
\hline
\end{tabular}


Badaruddin dkk. Empowerment of "meronce" hand

\begin{tabular}{|c|c|c|c|}
\hline $\mathrm{TF}$ & Transfer & Кеер & $\begin{array}{l}\text { Hampir sama dengan booked di } \\
\text { atas, keep biasanya dilakukan } \\
\text { oleh pembeli yang sudah pasti } \\
\text { akan membeli satu produk tapi } \\
\text { belum sempat melakukan } \\
\text { pembayaran. Hal ini dilakukan } \\
\text { agar barang tidak terjual kepada } \\
\text { orang lain. }\end{array}$ \\
\hline Return & $\begin{array}{l}\text { Penukaran barang yang } \\
\text { udah dibeli dengan } \\
\text { barang yang lain }\end{array}$ & hit and run & $\begin{array}{l}\text { Istilah bagi konsumen yang } \\
\text { memesan barang tapi tidak } \\
\text { menepati janji untuk membayar }\end{array}$ \\
\hline Refund & $\begin{array}{l}\text { Transaksi dibatalkan, } \\
\text { barang dikembalikan } \\
\text { kepada penjual dan uang } \\
\text { dikembalikan kepada } \\
\text { pembeli }\end{array}$ & Shipping cost & $\begin{array}{l}\text { Biasa disebut dengan ongkir } \\
\text { (ongkos kirim). Biaya kirim } \\
\text { yang dibebankan kepada } \\
\text { pembeli }\end{array}$ \\
\hline Reject & $\begin{array}{l}\text { Barang tidak dalam kondisi } \\
\text { baik, ada cacat }\end{array}$ & $\begin{array}{l}\text { Cash on } \\
\text { Delivery } \\
\text { (COD) }\end{array}$ & $\begin{array}{l}\text { Transaksi jual beli } \\
\text { produk di mana antara penjual } \\
\text { dan pembeli saling bertemi di } \\
\text { tempat yang telah disepakati. }\end{array}$ \\
\hline $\begin{array}{l}\text { Ready } \\
\text { stock }\end{array}$ & Barang tersedia & $\begin{array}{l}\text { PO (Pre- } \\
\text { Order) }\end{array}$ & $\begin{array}{l}\text { Sistem yang banyak dipakai } \\
\text { untuk menjual barang impor } \\
\text { atau custom. Jadi, barang baru } \\
\text { akan dipesankan } \\
\text { atau diproduksi setelah jadwal } \\
\text { PO berakhir dan dikirim setelah } \\
\text { barang } \\
\text { jadi. }\end{array}$ \\
\hline restock & $\begin{array}{l}\text { Barang yang stoknya } \\
\text { telah habis habis tersedia } \\
\text { kembali }\end{array}$ & Out of stock & $\begin{array}{l}\text { Barang yang habis } \\
\text { persediannya baik pada penjual } \\
\text { maupun suppier }\end{array}$ \\
\hline
\end{tabular}

Sumber: www.onino.web.id dalam Endriastuti \& Maurisia, 2014

Salah satu hasil penelitian yang juga dipaparkan kepada kelompok mitra adalah seperti hasil penelitian yang dilakukan oleh Amanda, dkk (2017) yang berujudul "Pengaruh Konten Post Instagram terhadap Online Engagement: Studi Kasus pada Lima Merek Pakaian Wanita". Hasil penelitian ini ditemukan bahwa Tipe post memiliki pengaruh signifikan terhadap online engagement (like dan komentar). Tipe post yang paling mempengaruhi online engagement secara signifikan adalah event. Waktu post (hari dan bulan) memiliki pengaruh signifikan terhadap online engagement (like dan komentar). Hari yang paling mempengaruhi secara signifikan online engagement adalah hari Kamis, Rabu, dan Jumat. Bulan yang paling memiliki pengaruh signifikan terhadap online engagement adalah bulan Maret, Juni, Juli, dan Desember. Online shop pakaian wanita bisa mengunggah tipe post event lebih sering lagi untuk meningkatkan online engagement. Online shop juga perlu mempertimbangkan hari Kamis, Rabu, dan Jumat sebagai waktu yang tepat untuk mengunggah post. Online shop dapat menggunakan kalender untuk melihat event yang bisa dikaitkan terhadap post, seperti hari raya, akhir tahun, dan waktu di saat terdapat event yang bisa diikuti oleh online shop untuk menarik banyak online engagement.

Setelah praktek pemasaran on-line ini selesai dilakukan, disepakati dengan ketua kelompok, mereka akan memasarkan produknya melalui on-line, dan apabila ada kendala maka dapat disampaikan pada ketua kelompok untuk nantinya disampaikan kepada tim pengabdian. 


\subsection{Evaluasi dan Monitoring}

Indikator keberhasilan kegiatan pengabdian ini dalam menjalankan program dapat dilihat dari kesesuaian proses dengan apa yang direncanakan, kesesuaian dalam pencapaian tujuan, penggunaan dan pemanfaatan sumberdaya yang efektif dan efisien, serta kemampuan dalam memberikan jaminan terhadap kesesuaian proses dan pencapaian tujuan melalui satu mekanisme kendali yang harmonis dan melekat utuh dalam sistem. Untuk mencapainya, maka diperlukan suatu proses yang dikenal dengan istilah "monitoring".

Proses monitoring terhadap pelaksanaan pengabdian dilakukan untuk memperoleh fakta-fakta, data, dan informasi dalam proses upaya pencapaian tujuan, apakah sesuai dengan standar yang telah ditetapkan atau untuk mengidentifikasi permasalahan yang dialami kelompok mitra dan tim pengabdian dalam proses pemberdayaan. Monitoring mengharuskan tim pengabdian untuk secara langsung melihat proses yang terjadi, juga dengan dukungan dokumen-dokumen dan pendapatpendapat dari yang dimonitor, hal ini dilakukan sebagai validasi dan keabsahan proses monitoring. Data-data dan fakta tersebut selanjutnya dijadikan sebagai rujukan untuk melakukan evaluasi terhadap projek yang dikerjakan, atau bahkan terhadap program yang telah diselesaikan.

Secara umum kegiatan pengabdian masyarakat yang dilakukan sudah sesuai dengan rencana yang disusun. Tahapan-tahapan yang direncanakan sudah terpenuhi dan dapat diselesaikan, mulai tahap identifikasi, pengurusan izin, Ceramah dan Diskusi, penyerahan peralatan dan bahan "meronce", pemasangan Papan Plang Pengabdian, serta monitoring dan evaluasi.

Monitoring dan evaluasi dilakukan oleh tim pelaksana sebanyak 2 (dua) kali yaitu pada tanggal 11 September 2019 (sejalan dengan pemasangan Plang Pengabdian Masyarakat dan Monev yang dilakukan oleh LPPM USU). Kegiatan Monev ke-1 (satu) ini dihadiri oleh Kepala Desa dan aparatnya, Ketua PKK, dan Ketua kelompok mitra beserta beberapa anggotanya. Kegiatan Monev 1 dilakukan di Kantor Kepala Desa. Pada Monev ini, Tim Pelaksana meminta masing-masing kelompok untuk membawa hasil kerajinanya meronce dan menunjukkan postingan pemasaran produk meronce di Instagram dan Facebook, sebagai bukti bahwa mereka telah mengerjakan kegiatan tersebut di kelompoknya. Dan dari Monev 1 ini dapat diketahui bahwa telah ada konsumen yang memesan hasil kerajinan mereka lewat online.

Kegiatan Monev ke 1 (pertama) dilakukan pada tanggal 11 September 2019. Pada kegiatan Monev 2 ini, tim pelaksana bertemu dengan aparat desa dan Ketua Kelompok Mitra. Pada pertemuan ini didiskusikan aktifitas yang sudah dilakakan oleh masing-masing kelompok mitra. Kelompok mitra menyebutkan bahwa mereka sudah melakukan pertemuan-pertemuan di waktu senggang untuk secara bersama-sama latihan memasarkan produk meronce dan produk-produk lainnya secara online. Tim pelaksana menyampaikan agar kegiatan memasarkan produk secara online tersebut hendaknya dapat dilakukan secara rutin, sehingga produk yang dipasarkan dapat menjangkau banyak orang.

Kegiatan Monev ke 2 (kedua) dilakukan pada tanggal 24 Oktober 2019. Kegiatan Monev ke 2 (dua) ini dihadiri oleh Kepala Desa dan aparatnya, Ketua PKK, dan Ketua kelompok mitra beserta beberapa anggotanya. Kegiatan Monev 2 dilakukan di Kantor Kepala Desa. Pada Monev ini, Tim Pelaksana meminta masing-masing kelompok untuk membawa hasil kerajinanya meronce dan menunjukkan postingan pemasaran produk meronce di Instagram dan Facebook, sebagai bukti bahwa mereka telah mengerjakan kegiatan tersebut di kelompoknya.

Secara keseluruhan, kegiatan pengabdian masyarakat ini disambut baik oleh Kepala Desa dan jajarannya dengan harapan kegiatan seperti ini masih dapat dilanjutkan pada tahun-tahun berikutnya untuk kelompok-kelompok lainnya dan untuk kegiatan-kegiatan lain yang ada di desa tersebut. Sambutan yang cukup baik terlihat dari kesiapan aparat desa dalam memfasilitasi kegiatan pengabdian masyarakat ini.

Kelompok Mitra juga menyambut baik kegiatan ini dan berharap dapat terus berlanjut pada masa yang akan datang. Dengan kegiatan pengabdian masyarakat ini bertambah pengetahuan anggota kelompok terkait dengan pemasaran online. Kelompok Mitra merasa sangat terbantu 
sekali, karena salah satu persoalan yang mereka hadapi selama ini adalah ketidakmampuan mereka memasarkan produk meronce secara online.

Dari hasil evaluasi diperoleh hasil dan manfaat dari kegiatan pengabdian ini diantaranya adalah meningkatkan keterampilan dan pengetahuan mitra dalam memanfaatkan Instagram dan Facebook sebagai alat untuk memasarkan produk meronce secara online. Kegiatan lokakarya ini hendaknya dilakukan pada sasaran yang lebih luas dan materinya dapat dikembangkan pada pemasaran dengan memanfaatkan marketplace seperti Tokopedia, Shopee, Bukalapak, dan lainlain. Dengan demikian diharapkan kelak dapat membantu mitra dalam mengembangkan usaha kerjainan meronce.

\section{KESIMPULAN}

Dari hasil kegiatan pengabdian masyarakat seperti telah diuraikan pada bagian terdahulu, maka dapat ditarik beberapa kesimpulan, yaitu: 1) Masyarakat Desa Dolok Merawan pada umumnya dan anggota kelompok mitra pada khususnya sangat menyambut baik kegiatan pengabdian masyarakat yang dilakukan oleh Tim Universitas Sumatera Utara; 2) Pengetahuan anggota kelompok mitra semakin bertambah khususnya yang terkait dengan pengetahuan pemasaran produk secara on-line, hal ini menunjukkan bahwa kapasitas kelompok menjadi semakin baik; dan 3) Cakrawala berpikir anggota kelompok mitra semakin terbuka dalam melihat peluang-peluang ekonomi yang dapat dipasarkan secara on-line di tengah-tengah lingkungan mereka yang dapat dimanfaatkan untuk pemberdayaan ekonomi masyarakat desa.

\section{UCAPAN TERIMAKASIH}

Artikel ini merupakan salah satu hasil dari Program Pengabdian kepada Masyarakat yang Dibiayai oleh dana NON PNBP Universitas Sumatera Utara. Oleh karena itu, diucapkan terima kasih kepada Rektor Universitas Sumatera Utara atas dukungan dana dan fasilitas yang diberikan. Terima kasih juga kepada Mitra pada kegiatan pengabdian ini.

\section{DAFTAR PUSTAKA}

Amanda, dkk. 2017. Pengaruh Konten Post Instagram terhadap Online Engagement: Studi Kasus pada Lima Merek Pakaian Wanita. JURNAL TEKNIK ITS Vol. 6, No. 1.

Badaruddin, Lina Sudarwati, dan Ermansyah. 2018. Pemberdayaan Sosial Ekonomi Kaum Perempuan Melalui Usaha Kegiatan Kerajinan Tangan "Meronce" Dalam Rangka Menopang Ekonomi Keluarga di Desa Dolok Merawan, Kecamatan Dolok Merawan, Kabupaten Serdang Bedagai, Provinsi Sumatera Utara. Laporan Pengabdian Masyarakat Mono Tahun (Talenta). LPPM USU.

Irfan Ahmad. 2019. The Most Popular Social Media Platforms of 2019. https://www.digitalinformationworld.com/2019/01/most-popular-global-social-networksapps-infographic.html.

Marzali, Amri, 2003. Strategi Peisan Cikalong dalam Menghadapi Kemiskinan, Jakarta: Yayasan Obor Indonesia

Onny S. Prijono dan A.M.W Pranarka (eds), 1996. Pemberdayaan : Konsep, Kebijakan dan Implementasi. Jakarta: CSIS, 
Badaruddin dkk. Empowerment of "meronce" hand

Silitonga Ruben. Diklat Kepemimpinan Dan Pelayanan Publik di Era Revolusi Industri 4.0. Buletin Pusdiklat Kemenristekdikti, Edisi 1 Volume 2 Tahun 2018.

S. McGurk, "What is Social Media Engagament and Why it Matters for your Business, " 6112014 [Online]. Available: http://blog.fusionfarm.com/what-is-social-media-engagement-andwhyit-matters-for-your-business.

Profil Desa Dolok Merawan, 2018. 